\title{
Proximate and Mineral Composition of Sesamum Indicum
}

\section{Seed}

\section{Christian Ebere E $^{*}$, Stanley Chukwuemeka I $^{1}$ and Emmanuel}

\section{Chinedu $\mathbf{I}^{2}$}

${ }^{1}$ Department of Chemistry, Imo State University (IMSU), Nigeria

${ }^{2}$ Quality Assurance and Control Department, Nigeria

\section{Research Article \\ Volume 3 Issue 4}

Received Date: November 25, 2019

Published Date: December 18, 2019

DOI: $10.23880 /$ macij-16000152

*Corresponding author: Enyoh Christian Ebere, Group Research in Analytical Chemistry, Environment and Climate Change (GRACE\&CC), Department of Chemistry, Imo State University (IMSU), Imo State, Nigeria, Email: cenyoh@gmail.com

\section{Abstract}

This research work presents the proximate and mineral characterization of seeds of Sesame indica. The seeds were procured from markets in Owerri and analyzed following standard procedure. Results from the proximate analysis showed moisture $(6.21 \pm 2.41 \%)$, ash $(8.46 \pm 0.24 \%)$, crude fibre $(6.12 \pm 4.10 \%)$, crude protein $(14.73 \pm 6.39 \%)$ and carbohydrate $(64.00 \pm 86.14 \%)$. Mineral analysis result showed sodium $(0.80 \pm 0.09 \%)$, potassium $(1.12 \pm 0.32 \%)$, calcium $(0.44 \pm 0.10 \%)$, magnesium $(0.29 \pm 0.45 \%)$, zinc $(0.82 \pm 0.21 \%)$ and iron $(1.02 \pm 0.11 \%)$. The distribution showed that sodium and zinc had the highest percentage (18\%) while the lowest was magnesium (6\%). This study showed that the sesame seed oil is a good source of vitamin and could be useful as food supplement and industry. Generally, the results obtained in this present study suggest that $S$. indicum seed investigated can be good source of protein, carbohydrate, minerals and crude fibre. Therefore could be exploited as commercial source to supplement both animal and human consumption consider the anti-nutrient factors.

Keywords: Seed; Micronutrients; Food; Minerals; Supplement; Proximate

\section{Introduction}

According to data from Food and Agriculture Organization, 963 million people globally are undernourished mainly due to increase of food prices, increasing population, shortage of fertile land and restrictions on the importation of food [1]. This number is expected to increase considering the ongoing global financial and economic crisis [2]. In order to fight the problem, attentions have recently shifted to search of local food sources [3]. Therefore, analysis and nutritional value of local indigenous plants, wild herbs and edible seeds rich in protein are of great significance [4]. Reports have revealed that quite a large number of indigenous plant species are high in nutrients value [5]. However many of such plants have been identified but there's paucity of data regarding their proximate and mineral compositions, particularly for sesame. Sesame has been recommended as a potential source to solve the problem of micronutrients deficiencies in modern day nutrition. 


\section{Medicinal \& Analytical Chemistry International Journal}

Sesame indicum is a flowering plant in the genus Sesamum, also called benne. Numerous wild relatives occur in Africa and a smaller number in India [6]. It is widely naturalized in tropical regions around the world and is cultivated for its edible seeds, which grow in pods or buns. The world harvested 4.2 million metric tonnes of sesame seeds in 2013, with India and China as the largest producers. Sesame seed is one of the oldest oil seed crops known, domesticated well over 3000 years ago. Sesame has many species, most being wild and native to subSaharan Africa. Sesame indicum, the cultivated type, originated in India and is tolerant to drought-like conditions, growing where other crops fail [7].

Sesame seeds are used in the making of tahin (sesame butter) and halva, and for the preparation of rolls, crackers, cakes and pastry products in commercial bakeries [8]. There are numerous varieties and ecotypes of sesame adapted to various ecological conditions. However, the cultivation of modern varieties is limited due to insufficient genetic information. Two studies that used morphological characters to group genotypes into clusters found a w ide genetic diversity in Indian sesame genotypes. Multivariate analysis based on morphological characters provides genetic information that will allow the breeder to improve populations by selecting from specific geographic regions. So, aim of the present study was to examin to analyses the oil from seed of Sesame indica. The specific objective of this study is to evaluate the proximate and mineral composition of Sesame indica obtained from Owerri, Imo state.

\section{Material and Method}

\section{Source of Raw Material}

Seeds of Sesame indica were bought from the main market in Owerri, Imo State and were immediately transported to the laboratory for analysis.

\section{Preparation of the Sample}

The seeds were thoroughly washed with clean water separately accordingly, based on how they were collected. They were sun dried until a constant weight was achieved. They were then grounded using electric blender and were stored in a well labeled air-tight container for analysis.

\section{Analytical Procedure}

Proximate Characterization: The proximate composition was determined as described in previous reports [9-11].
Moisture content: The AOAC method no. 945.38 was used. $5 \mathrm{~g}$ of the sample were weighed into clean, dried and pre-weighed crucibles. The crucibles and their contents were dried in the moisture extraction oven at 1100C for 4 hours. The samples were then removed from the oven, cooled in a desiccator and reweighed. The samples were again put back into the oven and dried until a constant weight was obtained. This analysis was carried out in triplicate and the average value was recorded as moisture content.

$\%$ Moisture $=\frac{\text { Initial weight of sample }- \text { weight of over dried sample }}{\text { initial weight of sample }} \times 100$

Ash Content: The AOAC (1990) method No 942.05 was used. Clean dried crucibles were weighed on an electronic balance and $5 \mathrm{~g}$ of sample weighed into the crucibles. The samples were dried in the moisture extraction oven until constant weights were obtained. Then, the samples were transferred into the muffle furnace with a pair of tongs and ashed at 5500C for 4 hours until a white ash was obtained. The sample were removed from the furnace and cooled in a desiccator, and reweighed.

$$
\% \text { Ash Content }=\frac{\text { weight of ash }}{\text { initial weight of sample }} \times 100
$$

The percentage ash was calculated as followed and the average taken.

Crude Fibre: Method No. 942.05 (AOAC) was used. 2g of defatted sample was weighed into $250 \mathrm{ml}$ beaker containing $200 \mathrm{ml}$ of $0.125 \mathrm{M}$ tetraoxosulphate iv acid (Sulphuric acid). The mixture was heated in a steam bath at $70^{\circ} \mathrm{C}-90^{\circ} \mathrm{C}$ for 2 hours, and then allowed to cool. The cooled mixture was filtered using a muslin cloth over a Buckner funnel. The residue was washed three times with hot water to remove the acid and then put in a beaker containing $200 \mathrm{ml}$ of sodium hydroxide. The mixture was heated as before over a steam bath for 2 hours. The solution was filtered and the residue washed three times with hot water, then with alcohol and water. The final residue obtained was put in clean pre-weighed crucible and dried at $1200 \mathrm{C}$ to a constant weight. The crucible with the oven dried sample as put in a muffle furnace and ashed at $550^{\circ} \mathrm{C}$ for 30 minutes such that the sample became ash white. The crucible and its contents were removed from the furnace, cooled in a dessicator and reweighed. Percentage fibre was calculated as followed:

$$
\% \text { Crude fibre }=\frac{\text { weight of dried sample }- \text { weight of ash }}{\text { initial weight of sample }} \times 100
$$




\section{Medicinal \& Analytical Chemistry International Journal}

The analysis was done in triplicate and the average taken as percentage crude fibre.

Crude Protein: Method no. 955.04C called the Kjeldahl method was used. This method was divided into three namely, digestion, distillation and titration.

a) Digestion: Approximately $0.2 \mathrm{~g}$ of ground air dried seed sample was weighed into clean dried Kjeldahl flask for digestion, and $0.1 \mathrm{~g}$ copper tetraoxosulphate iv crystals, $0.5 \mathrm{~g}$ sodium tetraoxosulphate iv crystal and $25 \mathrm{ml}$ of concentrated $\mathrm{H}_{2} \mathrm{SO}_{4}$ acid were added into the flask and some glass beads were added into the flask content as anti-bumping agents. The Kjeldahl flask and its content were transferred to the digesting chamber in a fume cupboard and digested. Digestion continued with constant rotation of the digestion flask until the sample changed colour (that is from black to light blue). The digestion flask was then removed from the digesting chamber and allowed to cool. The digest was made up to $100 \mathrm{ml}$ using distilled water and shaken vigorously to a homogenous solution.

b)Distillation: Out of the homogenous solution of the digest, $20 \mathrm{ml}$ was transferred into a distillation flask using a pipette. Then $20 \mathrm{ml}$ of $40 \%$ sodium hydroxide solution was added carefully down the side of the flask through a funnel. Then $50 \mathrm{ml}$ of $2 \%$ boric acid solution was pipetted into a receiving flask and two drops of methyl red indicator added. The distillation unit was fitted such that the condenser was connected to the receiving flask with a glass tube, and the condenser cooled with constant supply of cold water from tap. Also, the tip of the glass tube was immersed in the boric acid. The distillation unit was then heated on a heating mantle until the pink solution of the boric acid turned blue and the volume increased to about $100 \mathrm{ml}$ by the distillate.

c) Titration: Ten milliliters of the distillate was titrated against $0.1 \mathrm{~N}$ hydrochloric acid to a colorless end point. A blank solution was also titrated to get any trace of nitrogen in the blank. All the titre volumes were recorded. The percentage crude protein was calculated as follows:

$$
\% \text { Crude protein }=\% \text { Nitrogen } \mathrm{X} 6.25
$$

Where,

$$
\% \text { Nitrogen }=\frac{28}{100} x \frac{v_{t}-v_{b}}{w_{o}}
$$

$\mathrm{V}_{\mathrm{t}}=$ titre volume of sample, $\mathrm{V}_{\mathrm{b}}=$ titre volume of blank, $\mathrm{W}_{\mathrm{o}}$ = weight of sample.
Carbohydrate: The carbohydrate content of the sample was obtained by difference, that is, as the difference between the total summations of percentage moisture, fat, fibre, protein, Ash and 100

$$
\begin{gathered}
\% \text { carbohydrate }=100-(\% \text { moisture }+\% \text { fat }+\% \text { protein } \\
+\% \text { fibre }+\% \text { ash })
\end{gathered}
$$

Mineral Content Analysis: The mineral analysis was done according to Enyoh CE, et al. [9,12], Ibrahim Sani, et al. [13], Ibe FC, et al. [14,15]. The mineral content of the fruit extracts were extracted using aqua-regia $\left(\mathrm{HNO}_{3}: \mathrm{HCl}\right.$ in ratio 1:3). $2 \mathrm{~g}$ of the seed powder were accurately weigh into a test tube, then $20 \mathrm{ml}$ of aqua-regia were added. The mixture were allow to stand for $24 \mathrm{hrs}$, then filtered. The filtrate was used for the mineral analysis using Perkins Elmer A Analyst 400 Atomic Absorption Spectrophotometer.

\section{Data Analysis}

All statistical analysis was computed with IBM SPSS statistic 20. The results were expressed as mean and standard deviation.

\section{Result and Discussion}

The data for the proximate analysis is presented in table 1 . The moisture content recorded was $6.21 \pm 2.41 \%$ These values contradict the report of Dashak and Fali [16] who reported the moisture content values of $4.12-4.73 \%$ and Mbaebie [17] who reported the moisture content values of $5.60 \pm 3.74 \%$ for seeds of Sesamum indicum $L$. grown in Southeastern Nigeria. The moisture contents observed in the seed may disable the seed to possess a long storage capability and thus rapid deterioration $[9,12,18]$.

\begin{tabular}{|c|c|}
\hline Parameters & Concentration(\%) \\
\hline Moisture & $6.21 \pm 2.41$ \\
\hline Ash & $8.46 \pm 0.24$ \\
\hline Crude fibre & $6.12 \pm 4.10$ \\
\hline Crude protein & $14.73 \pm 6.39$ \\
\hline Carbohydrate & $64.00 \pm 86.14$ \\
\hline
\end{tabular}

Value reported as Mean \pm SD for triplicate analysis $n=3$

Table 1: Proximate composition of the seed.

Ash refers to the inorganic residue remaining after either ignition or complete oxidation of organic matter in a food sample. The inorganic residue consists mainly of the minerals present in the food sample. The ash contents recorded was $8.46 \pm 0.24 \%$. The obtained result is comparable to $8.94 \pm 0.96 \%$ reported for seeds of 


\section{Medicinal \& Analytical Chemistry International Journal}

Sesamum indicum L. grown in Southeastern Nigeria. Crude fibre is a measure of the quantity of indigestible cellulose, pentosans, lignin, and other components of this type in present foods. These components have little food value but provide the bulk necessary for proper peristaltic action in the intestinal tract [19]. The recorded crude fibre was $6.12 \pm 4.10 \%$, which is also comparable to reported value elsewhere. According to Bowmen and Russell [20], values of ash and crude fibre content are important in terms of the suitability of food vegetable and digestibility. Furthermore, National Research Council [21] recommended that crude fibre contents of sesame indicum $L$. may contribute to the daily needs of fibre. Recently, the interest in dietary fibre has been stimulated due to its ability to prevent chronic diseases such as cardiovascular disease, cancer and diabetes mellitus. However, lower or higher intake of fibre may results to bowel irritation and possibly colon cancer. The obtained crude protein recorded was $14.73 \pm 6.39 \%$. Crude protein is the amount of protein of animal feed or specific food. Crude protein depends on the nitrogen content of the food proteins. Carbohydrates have several roles in living organisms, including energy transportation. Carbohydrate derivatives are also involved in reproduction, the immune system, the development of disease, and blood clotting. The recorded carbohydrate content was $64.00 \pm 86.14 \%$ which lower compared to other studies. The good distribution of nutrients in the seeds suggests the potential usage of this plant as a forage feed given to the domestic animals and human consumption.

Minerals are required in small amounts, to make the body function properly. Minerals are essential in meeting the essential nutritional needs of humans. They regulate water retention and maintenance for the activation of various metabolic processes within the body. The functional roles of these elements (sodium, potassium, calcium, magnesium, zinc and iron) are well documented but must be taken appropriately to meet the daily requirement. Data obtained on elemental concentrations of seed of $S$. indicum may be useful in deciding the dosage or quantity for consumption as well as herbal remedies of this plant. The mineral compositions of the seed sample were reported in Table 2 and the distribution in Figure 1. Sodium and zinc had the highest percentage $(18 \%)$ while the lowest was magnesium (6\%). Among the various elements investigated by, magnesium (0.61-0.24\%), sodium (0.63-0.23\%) and phosphorous (0.55-0.20\%) are found to be present at the minor levels in all the various parts of the plant while calcium (2.41-0.90\%) and potassium (0.70- $0.20 \%$ ) are the predominant minerals as compared with others. Contrasting results obtained could be due to environmental factor such as different geological area, growing soil and climate.

\begin{tabular}{|c|c|}
\hline Phytochemicals & Concentration (mg/g) \\
\hline Sodium & $0.80 \pm 0.09$ \\
\hline Potassium & $1.12 \pm 0.32$ \\
\hline Calcium & $0.44 \pm 0.10$ \\
\hline Magnesium & $0.29 \pm 0.45$ \\
\hline Zinc & $0.82 \pm 0.21$ \\
\hline Iron & $1.02 \pm 0.11$ \\
\hline
\end{tabular}

Value reported as Mean \pm SD for triplicate analysis $n=3$

Table 2: Mineral composition of the seed.

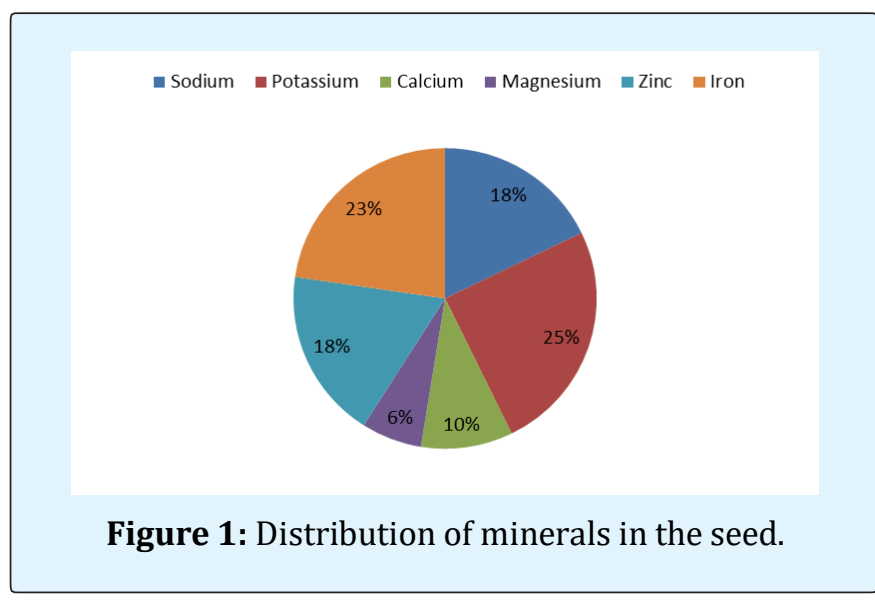

\section{Conclusion}

Generally, the results obtained in this present study suggest that $S$. indicum seed investigated can be good source of protein, carbohydrate, minerals and crude fibre. Therefore could be exploited as commercial source to supplement both animal and human consumption consider the anti-nutrient factors.

\section{References}

1. Food and Agricultural Organization (2008) The State of Food Insecurity in the World. pp: 6.

2. Weaver LT (1994) Feeding the weanling in the developing world: problems and solutions. Int J Food Sci Nutri 45(2): 127-134.

3. Singh BB, Emechebe AM, Atokple IDK (1993) Inheritance of Alectra resistance in cowpea genotype B 301. Crop Science 33: 70-72.

4. Obiajunwa EI, Adebiyi FM, Omode PE (2005) Determination of essential minerals and trace 


\section{Medicinal \& Analytical Chemistry International Journal}

elements in Nigerian sesame seeds, using TXRF technique. Pakistan Journal of Nutrition 4(6): 393395.

5. Bankole MA, Shittu LAJ, Ahmed TA, Bankole MN, Shittu RK, et al. (2007) Synergistic antimicrobial activities of phytoestrogens in crude extract of two Sesame species against some common pathogenic microorganism. Afr J Traditi Compliment Altern Med 4(4): 427-433.

6. Ihenetu SC, Enyoh CE, Inyamah PC, Enyoh EC (2019) Physicochemical Properties, Phytochemicals and Fat Soluble Vitamins of Seed Oil Extracts from Sesamum Indicum L. International Journal of Chemical and Biological Sciences 1(4): 8-12.

7. Che-Man YB, Swe PZ (1995) Thermal analysis of failed-batch Palm oil by differential scanning calorimetry. J Am Oil Chem Soc 72(12): 1529-1532.

8. Aremu MO, Olanisakin A, Bako DA, Madu PC (2006) Compositional studies and physiochemical characteristics of cashew nut (Anarcadium Occidentale) flour. Pakistan Journal of Nutrition 5(4): 328-333.

9. Enyoh CE, Ihionu EA, Verla AW, Ebosie NP (2017) Physicochemical Properties of Palm Oil and Soil from Ihube Community, Okigwe, Imo State, Nigeria. International Letters of Natural Science 62: 35-49.

10. Nwachukwu CD, Enyoh EC, Enyoh CE, Amaobi CE (2018) Effect of Fermentation Time on the Proximate and Mineral Composition of Fermented African Oil Bean Seed 'Ugba'. Sustainable Food Production 2: 1320.

11. Association of Official Analytical Chemists (1990) AOAC, Official Methods of Analysis. 15 th (Edn.), Arlington Virginia, USA, pp: 951-959.

12. Enyoh EC, Enyoh CE, Amaobi CE (2017) Quality Assessment of Palm Oil from Different Palm Oil Local Factories in Imo State, Nigeria. World Scientific News 88(2): 152-167.
13. Ibrahim Sani, Fatima Ajuma Sule, Aliyu Ahmad Warra, Fatima Bello, Isah Musa Fakai, et al. (2013) Phytochemicals and Mineral Elements Composition of White Sesamum indicum L. Seed Oil. International Journal of Traditional and Natural Medicines 2(2): 118-130.

14. Ibe FC, Ibe BO, Enyoh CE (2019) Trace metal, FTIR and phytochemical analysis of Viscum album leaves harvested from Pentaclethra macrophylla. World News of Natural Sciences 25: 61-71.

15. Ibe FC, Isiukwu BO, Enyoh CE (2017) Trace metals analysis of soil and edible plant leaves from abandoned municipal waste dumpsite in Owerri, Imo state, Nigeria. World News of Natural Sciences (WNOFNS) 13: 27-42.

16. Dashak DA, Fali CN (1993) Chemical composition of four varieties of Nigeria benniseed. Food Chemistry 47(3): 253-255.

17. Mbaebie B, Garuba O, Augustina U, Sunday O (2010) Chemical Composition of Sesamum indicum $L$. (Sesame) Grown in Southeastern Nigeria and the Physicochemical Properties of the Seed Oil. Seed Science and Biotechnology 4(1): 69-72.

18. Enyoh CE, Verla AW, Enyoh EC, Verla EN (2018) A Review on the Quality of Palm Oil (Elaeis guineensis) Produced Locally in Imo State, Nigeria. Sustainable Food Production 4: 40-50.

19. Behrotest Equipment for the Determination of Crude Fibre http://partners.laborbehr.com/pdf/37/p_crude_fibre .pdf. Assessed 24/11/2019.

20. Bowmen BA, Russel RM (2001) Present Knowledge in Nutrition. $8^{\text {th }}$ (Edn.), International Life Sciences Institute, USA, pp: 43-104.

21. NRC (1975) National Research Council. Recommended Dietary Allowance. USA Nutrition Review 395: 374-395. 